\title{
ПИТАННЯ ПОТЕРПІЛОГО У СКЛАДІ ЗЛОЧИНУ, ПЕРЕДБАЧЕНОГО СТ. 164 КК УКРАЇНИ
}

\begin{abstract}
МАРИСЮК Костянтин Богданович - доктор юридичних наук, доцент, професор кафедри кримінального права і процесу Навчально-наукового інституту права, психології та інноваційної освіти Національного університету «Львівська політехніка"

КОМАРНИЦЬКА Мар'яна Петрівна - студентка Навчально-наукового інституту права, психології та інноваційної освіти Національного університету «Јьвівська політехніка"
\end{abstract}

DOI:10.32782/NP.2019.4.17

УДК 343.82

Статья посвящена рассмотрению понятия «дети» и контексте ст. 164 УК Украинъ. Сделан въгвод, что понятием «дети» в этой статье охвачено следующие категории лич: 1) несовершеннолетние, то есть лища, не достигшие восемнадцатилетнего возраста; 2) нетрудоспособнъе дети, то есть те, которье изза ббзических или психических недостатков лишены возможности постоянно или временно работать (в первую очередь - дети-инвалидъ I и II группъ); 3) несовершеннолетние лица до момента наступления юридического совершеннолетия, если это произошло до достижения ими 18-летия; 4) совершеннолетние дети в возрасте до 23 лет, которье продолжанот обучение и в связи с этим нуждаются в материальной помощи родителей.

Ключевъе слова: дети, несовершеннолетние, родители, алименть, уголовная ответственность.

Постановка проблеми

Права дитини є поняттям з категорії прав людини і випливають із гідності і неповторності дитини як людської особистості.

Права дітей, як і права людини, розглядаються в аспекті «влада - особа». Якщо дитина має право, то це означає, що держава повинна забезпечити їй можливість користуватися цим правом.

Права дитини, як і права людини, підлягають обмеженням, але тільки таким, які передбачаються законом і які є необхідними в демократичному суспільстві в інтересах державної безпеки, громадського порядку та запобігання злочинам, для охорони здоров'я або моралі чи з метою захисту прав і свобод інших осіб. Не можуть бути, наприклад, обмежені права на захист від тортур, нелюдських або таких, що принижують гідність, видів поводження і покарання та захист від рабства та підневільного стану.

Для того, щоб захистити права дітей, законодавством України серед іншого передбачені механізми призначення, виплати та стягнення коштів на їх утримання, а за ухилення від їх виплати - юридичну відповідальність, включно з кримінальною.

Не зважаючи на безліч публікацій в досліджуваній сфері, до сих пір залишаються питання, одним з яких - кого ж слід включати до категорії «діти», використаної в назві ст. 164 Кримінального кодексу (КК) України? Цьому питанню й присвячено запропоновану статтю.

\section{Стан дослідження}

Досліджувану проблему у своїх працях в тому чи іншому контексті розглядали такі вчені, як І. Бандурка, В. Гончаренко, М. Коржанський, О. Аитвинов, І. Семеногов та інші.

Мета статті - встановлення основних підходів до поняття «дитина» та, за їх допомогою, визначення переліку категорій осіб, які входять до згаданої категорії у контексті ст. 164 КК України.

\section{Виклад основного матеріалу}

Чинний КК України містить ст. 164, яку називає «Ухилення від сплати аліментів на ко- 
ристь дітей». Кого ж законодавець відносить до категорії «дітей» у контексті згаданої статті?

Не зважаючи на здавалось би зрозумілість досліджуваного поняття, навіть на рівні міжнародного законодавства немає абсолютного порозуміння.

Наприклад, Конвенція про мінімальні норми соціального забезпечення 1952 р. вказує, що, у контексті цього документу, термін «дитина» означає дитину, яка не досягла віку закінчення шкільної освіти або не досягла 15-річного віку, як це може бути встановлено[1].

Європейський кодекс соціального забезпечення 1990 р. під дитиною розуміє дитину шкільного віку або дитину, яка не досягла 16 років[2].

В той же час, більшість актів, прийнятих як Організацією Об'єднаних Націй, так і уповноваженими органами Ради Европи, все ж сходяться на думці, що максимальним граничним віком для поняття «дитина» має вважатись 18-річний вік або вік досягнення повноліття.

Так, Конвенція Ради Свропи про громадянство 1997 р. наголошує, що «дитина» означає будь-яку особу, що не досягла 18 років, якщо за законодавством, яке застосовується до дітей, повноліття не настає раніше[3].

Конвенція Ради Європи про заходи щодо протидії торгівлі людьми 2005 р. вказує, що «дитина» - це будь-яка особа віком до 18 років[4].

Розділяє позицію щодо віднесення до категорії дітей всіх осіб, які не досягли 18-річного віку, й вітчизняне законодавство.

Так, наприклад, Сімейний кодекс України 2002 р. наголошує, що: 1. Правовий статус дитини має особа до досягнення нею повноліття; 2. Малолітньою вважається дитинна до досягнення нею чотирнадцяти років. Неповнолітньою вважається дитина у віці від чотирнадцяти до вісімнадцяти років[5].

Закон України про громадянство 2001 р. вказує, що дитина - це особа віком до 18 років[6].

Закон України про протидію торгівлі людьми 2002 р. аналогічно стверджує, що дитина - це будь-яка фізична особа віком до вісімнадцяти років[7].

Закон України про охорону дитинства 2001 р. також схиляється до наведених вище думок, пишучи, що дитина - це особа віком до
18 років (повноліття), якщо згідно з законом, застосованим до неї, вона не набуває прав повнолітньої раніше[8].

Кого ж відносити до категорії «дітей» у контексті ст. 164 КК України? Виходячи зі змісту названої норми, науковці зазвичай не сприймають досліджуване поняття виключно у переліченому вище буквальному значенні і закладають у нього дещо ширше кого суб'єктів. Наприклад, М. Коржанський писав, що до дітей, згідно ст. 164 КК України, належать неповнолітні (до 18-річного віку), а також діти, визнані інвалідами I чи II групи[9, с. 129].

Подібної думки дотримуються й М. Потебенько та В. Гончаренко, які пишуть, що потерпілими від досліджуваного злочину можуть бути неповнолітні діти (тобто особи, які не досягли 18 років) та непрацездатні повнолітні діти (ті, які визнані інвалідами першої або другої групи, або ті, які досягли пенсійного віку)[10, с. 159].

О. Литвинов вважає, що потерпілими від цього злочину можуть бути діти, на утримання яких за рішенням суду їх батько та / чи мати мають сплачувати аліменти, а також неповнолітні чи непрацездатні діти, що перебувають на утриманні батьків. Неповнолітніми дітьми визнаються особи віком до 18 років, якщо згідно із законом вони не набувають прав повнолітніх раніше (наприклад, внаслідок одруження). Непрацездатними $\epsilon$ діти, які в силу фізичних чи психічних вад позбавлені можливості постійно чи тимчасово працювати (це, зокрема, діти-інваліди I та II групи)[11, c. 166-167].

Перелічені вище дефініції загалом можна вважати тотожними у частині кола осіб, яких законодавець у назві ст. 164 КК України називає поняттям «діти» (не будемо звертати надмірної уваги на віднесення до категорії дітей, «які досягли пенсійного віку», віднісши наведене твердження до термінологічних неточностей).

Відтак, більшість науковців відносять до категорії «діти», у контексті ст. 164 КК України: 1. Неповнолітніх, тобто осіб, що не досягли вісімнадцятирічного віку; 2. Непрацездатних дітей, тобто тих, що які в силу фізичних чи психічних вад позбавлені можливості постійно чи тимчасово працювати (в першу чергу - дітей-інвалідів I та II групи). Проте, 


\section{Кримінальне право, кримінальний процес та криміналістика}

чи виключно ці категорії осіб розуміє законодавець під терміном «діти» у контексті ст. 164 КК України? Звернемо увагу на винятки з загального правила.

Як уже зазначалось, до поняття "діти» у ст. 164 КК України віднесено неповнолітніх, тобто осіб, які не досягли вісімнадцятирічного віку. Проте, це твердження не можна вважати абсолютним, оскільки законодавство України передбачає випадки, коли особа набуває юридичного повноліття і до досягнення 18-річчя. Згадана вище ситуація виникає, наприклад, у випадку укладення неповнолітньою особою шлюбу. Згаданий підхід є достатньо чітким та аргументованим, проте деякі дослідники роблять спроби його спростувати, пишучи, що «ст. 180 Сімейного кодексу України (СК) визначає обов'язком батьків утримувати дитину до досягнення нею повноліття (слід зазначити, що право на одержання утримання від батьків неповнолітня особа не втрачає навіть у зв'язку із фактичним укладенням нею шлюбу до досягнення віку, встановленого ч. 2 ст. $23 \mathrm{CK} »[12$, с. 176].

Ще одним з винятків з загального правила може вважатись ситуація, коли обов'язок сплачувати кошти на утримання дитини не припиняється і після фактичного досягнення останньою повноліття. Про згадану ситуацію пише, наприклад, I. Семеногов, зазначаючи, що «потерпілим від ухилення від сплати аліментів може бути не лише неповнолітня, а й повнолітня дитина, незалежно від ії працездатності. У ст. 199 СК «Обов'язок батьків утримувати повнолітніх дочку, сина, які продовжують навчання» встановлено: «якщо повнолітні дочка, син продовжують навчання і у зв'язку з цим потребують матеріальної допомоги, батьки зобов'язані утримувати їх до досягнення двадцяти трьох років за умови, що вони можуть надавати матеріальну допомогу»[13, с. 38].

Далі зазначений автор аргументує згадане твердження: «Ст. 199 СК передбачає: якщо повнолітні дочка, син продовжують навчання і у зв'язку з цим потребують матеріальної допомоги, батьки зобов'язані утримувати їх до досягнення двадцяти трьох років за умови, що вони можуть надавати матеріальну допомогу. Це право припиняється у разі припинення навчання. При цьому законодавство (ч. 3 ст. 199 СК) надає право тому з батьків, з ким проживає дочка, син (а також самих дочки чи сина, які продовжують навчання) на звернення до суду з позовом про стягнення аліментів. Отже, злісне ухилення від сплати коштів на утримання повнолітньої дитини, визначеного таким рішенням, також може містити ознаки злочину, передбаченого ст. 164 КК. Пленум Верховного Суду України у постанові № 3 від 15.05.2006 р. «Про застосування судами окремих норм Сімейного кодексу України при розгляді справ щодо батьківства, материнства та стягнення аліментів» зазначив: обов'язок батьків утримувати повнолітніх дочку, сина, які продовжують навчатися після досягнення повноліття (незалежно від форми навчання), виникає за обов'язкової сукупності таких юридичних фактів: досягнення дочкою, сином віку, який перевищує 18, але є меншим 23 років; продовження ними навчання; потреба у зв'язку з цим у матеріальній допомозі; наявність у батьків можливості надавати таку допомогу. Таким чином, за наявності зазначених підстав повнолітня дитина (у віці від 18-ти до 23-х років) також є аліментоуповноваженою, а отже - може бути потерпілим від злісного ухилення від сплати аліментів»[13, c. $40-41]$.

\section{Висновки}

Відтак, підсумовуючи викладене вище, можна зробити висновок, що поняттям «діти» у контексті ст. 164 КК України охоплено наступні категорії осіб: 1) неповнолітні, тобто особи, що не досягли вісімнадцятирічного віку; 2) непрацездатні діти, тобто ті, що які в силу фізичних чи психічних вад позбавлені можливості постійно чи тимчасово працювати (в першу чергу - дітей-інвалідів I та II групи); 3) неповнолітні особи до моменту набуття ними юридичного повноліття, якщо це відбулось до досягнення ними18-річчя; 4) повнолітні діти у віці до 23 років, які продовжують навчання і у зв'язку з цим потребують матеріальної допомоги батьків.

\section{Література}

1. Конвенція про мінімальні норми соціального забезпечення // База даних «Законодавство України» / ООН. // https://zakon.rada. gov.ua/laws/show/993_011/ed20160316\#n17 


\section{АНОТАЦІЯ}

Статтюо присвячено розгляду поняття «діти» у контексті ст. 164 КК Украӥни. 3роблено висновок, що поняттям «діти»у контексті ст. 164 КК України охоплено наступні категорї осіб: 1) неповнолітні, тобто особи, що не досягли вісімнадияттрічного віку; 2) непрацездатні діти, тобто ті, які в силу бозичних чи психічних вад позбавлені можливості постійно чи тимчасово працювати (в периу чергу - дітей-інвалідів I та II групи); 3) неповнолітні особи до моменту набуття ними юридичного повноліття, якщо ие відбулось до досягнення ними вісімнадиятиріччя; 4) повнолітні діти у вічі до 23 років, які продовжують навчання $i$ у зв'язку з иим потребують матеріальної допомоги батьків.

Ключові слова: діти, неповнолітні, батьки, аліменти, кримінальна відповідальність.

2. Европейський кодекс соціального забезпечення 1990 р. // База даних «ЗаконодавствоУкраїни»/Рада Европи. URL:https://zakon. rada.gov.ua/laws/show/994_651/ed19901106/ find?text $=\% \mathrm{E} 4 \% \mathrm{E} 8 \% \mathrm{~F} 2 \% \mathrm{E} 8 \% \mathrm{ED} \% \mathrm{E} 0$ (дата звернення 10.12.2019)

3. Європейська конвенція про громадянство 1997 р. // База даних «Законодавство України» / Рада Европи. URL : https://zakon. rada.gov.ua/laws/show/994_004/ed20090527/ find?text $=\% \mathrm{C} 4 \% \mathrm{E} 8 \% \mathrm{~F} 2 \% \mathrm{E} 8 \% \mathrm{ED} \% \mathrm{E} 0$ (дата звернення 10.12.2019)

4. Конвенція Ради Европи про заходи щодо протидії торгівлі людьми 2005 р. // База даних «Законодавство України» / Рада Европи. URL : https://zakon. rada.gov.ua/laws/show/994_858/ed20110301/ find?text $=\% \mathrm{C} 4 \% \mathrm{E} 8 \% \mathrm{~F} 2 \% \mathrm{E} 8 \% \mathrm{ED} \% \mathrm{E} 0$ (дата звернення 10.12.2019)

5. Сімейний кодекс України 2002 p. // База даних «Законодавство України» / ВP України. URL : https://zakon. rada.gov.ua/laws/show/2947-14/ed20130609/ find?text $=\% \mathrm{C} 4 \% \mathrm{E} 8 \% \mathrm{~F} 2 \% \mathrm{E} 8 \% \mathrm{ED} \% \mathrm{E} 0$ (дата звернення 10.12.2019)

6. Закон України про громадянство 2001 р. // База даних «Законодавство України» / ВР України. URL : https://zakon. rada.gov.ua/laws/show/2235-14/ed20121206/ find?text $=\% \mathrm{C} 4 \% \mathrm{E} 8 \% \mathrm{~F} 2 \% \mathrm{E} 8 \% \mathrm{ED} \% \mathrm{E} 0$ (дата звернення 10.12.2019)

\section{SUMMARY}

The article deals with the concept of "children" in the context of Art. 164 of the Criminal Code of Ukraine. It is concluded that the concept of "children" in the context of Art. 164 of the Criminal Code of Ukraine covers the following categories of persons: 1. minors, ie persons under the age of eighteen; 2. disabled children, who, due to physical or mental disabilities, are deprived of the opportunity to work permanently or temporarily (first of all - children with disabilities of groups I and II); 3. minors, until their legal age, if they have reached the age of eighteen; 4. Adult children under the age of 23 who continue their education and therefore need financial support from their parents.

Keywords: children, minors, parents, alimony, criminal liability.

7. Закон України про протидію торгівлі людьми 2002 р. // База даних «Законодавство України» / ВР України. URL : https://zakon. rada.gov.ua/laws/show/3739-17/ed20130609/ find?text $=\% \mathrm{C} 4 \% \mathrm{E} 8 \% \mathrm{~F} 2 \% \mathrm{E} 8 \% \mathrm{ED} \% \mathrm{E} 0$ (дата звернення 10.12.2019)

8. Закон України про охорону дитинства 2001 р. // База даних «Законодавство України» / ВР України. URL : https://zakon.rada.gov.ua/ laws/show/2402-14/ed20150705\#n10(дата звернення 10.12.2019)

9. Кримінальне право i законодавство України. Частина Особлива / За ред. М. Коржанського. К. : Атіка, 2001. 544 с.

10. Науково-практичний коментар до Кримінального кодексу України. Особлива частина. / Під загальною редакцією Потебенька М, Гончаренка В. К. : Форум, 2001. 942 с.

11. Науково-практичний коментар Кримінального кодексу України / За заг. ред. Аитвинова О.М.. К. : Центр учбової літератури, 2016. 528 с.

12.Сімейне право України : підручник / Ю. С. Червоний, О. В. Калітенко, Г. С. Волосатий, В. І. Труба ; за ред. Ю. С. Червоного. К. : Істина, 2004. 400 с.

13. Семеногов I. Кримінальна відповідальність за ухилення від сплати аліментів на утримання дітей або від сплати коштів на утримання непрацездатних батьків : дис. ... канд. юрид. наук : 12.00.08 / Семеногов Ігор Володимирович ; Харків. нац. ун-т внутр. справ. Харків, 2015. 215 с. 